\title{
Tórax 2
}

\author{
Natalia Posadas ${ }^{1}$ \\ ${ }^{1}$ Médico encargado del Servicio de Tomografía Computada Sanatorio \\ IMAC, Salta; Médico asociado del Servicio de Diagnóstico por \\ Imágenes del Hospital Italiano, Buenos Aires; Jefe de Trabajos \\ Prácticos de Cátedra de Diagnóstico por Imágenes de la Facultad de \\ Medicina UNT, Sede Salta, Argentina
}

Rev Argent Radiol 2019;83:45-46.
Address for correspondence Natalia Posadas, MD, Servicio de Tomografía Computada Sanatorio IMAC, Salta; Servicio de Diagnóstico por Imágenes del Hospital Italiano, Buenos Aires; Facultad de Medicina UNT, Sede Salta, Argentina (e-mail: natalia.posadas@gmail.com).

\section{Miguel Stoopen Rometti y Ricardo García Mónaco. Tórax 2. Buenos Aires: Ediciones Journal}

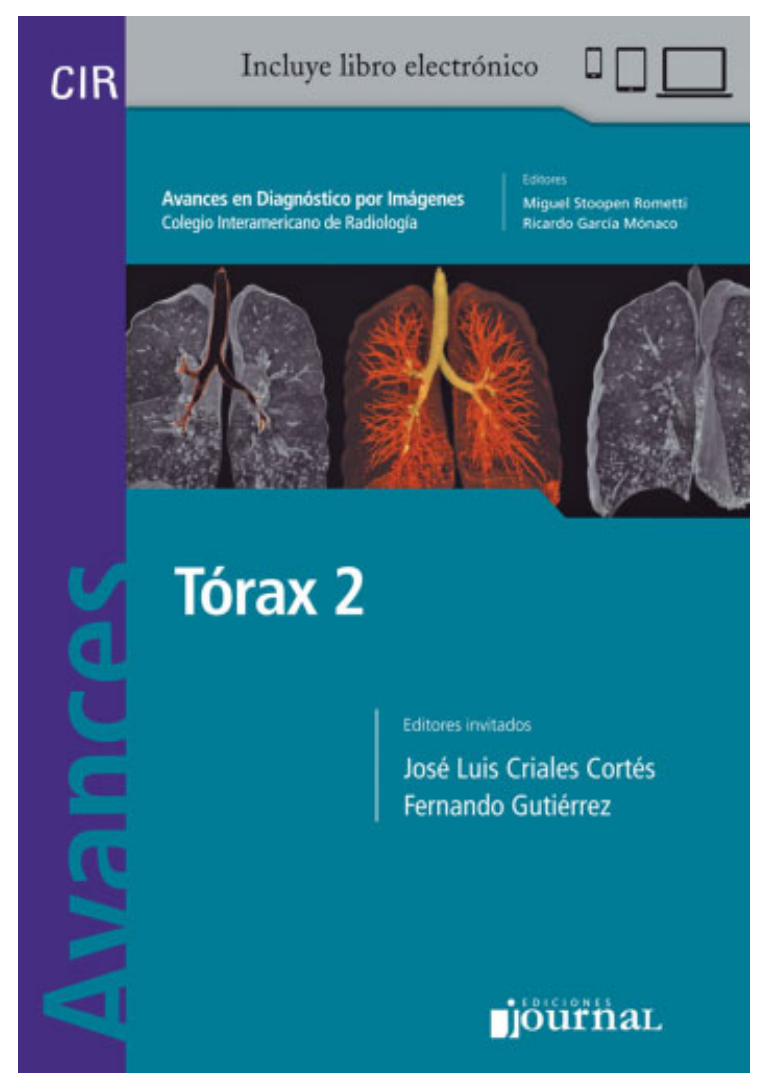

El desarrollo de Tórax 2 cuenta con la colaboración de reconocidos radiólogos nacionales e internacionales refe- rentes del área, sumamente comprometidos con la educación. De ello dan cuenta sus numerosas publicaciones y participación en cursos, congresos y programas de educación médica, entre otros. Ese antecedente queda reflejado en su capacidad para plasmar de manera práctica y de fácil entendimiento el desarrollo de las diferentes patologías que afectan al tórax y que se abordan en este libro. El capítulo de enfermedades difusas es un claro ejemplo de ello.

A lo largo de un poco más de 200 páginas, los autores introducen un contexto clínico de las patologías, para luego abocarse al desarrollo de los hallazgos imagenológicos de una forma detallada y a la vez fácilmente entendible, tanto para radiólogos en formación y radiólogos generalistas como para subespecialistas.

Luego de cada capítulo proponen, además, una bibliografía útil para avanzar en el desarrollo de cada tema, si fuera necesario.

Consta de 13 capítulos que abarcan numerosos temas de interés, desde la patología tumoral, enfermedades difusas del pulmón y enfermedades relacionadas con el hábito tabáquico, hasta temas de intervencionismo e imágenes moleculares.

Uno de los capítulos a destacar, por la actualidad del tema, es “Cribado de cáncer de pulmón," que plantea una puesta al día, haciendo un repaso de los estudios más relevantes, desde el NLST hasta los que se están llevando a cabo en la actualidad.

Por último, la mayoría de los capítulos desarrolla una perspectiva a futuro de lo que infieren será el desarrollo de las imágenes torácicas, dando especial interés y relevancia a la baja dosis y a nuevas técnicas, como la doble energía.

Recomiendo Tórax 2 para todos aquellos médicos interesados en conocer, repasar o avanzar en la valoración de la patología torácica de forma rápida y actualizada.
DOI https://doi.org/ $10.1055 / \mathrm{s}-0039-1683990$ ISSN 1852-9992.
Copyright $\odot$ 2019, Sociedad Argentina de Radiología. Publicado por Thieme Revinter Publicações Ltda., Rio de Janeiro, Brazil. Todos los derechos reservados.

\section{License terms}

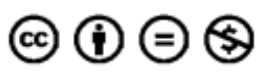

